\title{
GENDER, RELIGIUSITAS, LOVE OF MONEY, DAN ETIKA PENGGELAPAN PAJAK
}

\author{
DEKENY AGUSTINA NURACHMI, AMIR HIDAYATULLOH* \\ Program Studi Akuntansi, Universitas Ahmad Dahlan \\ *Email: amir.hidayatulloh@act.uad.ac.id
}

\begin{abstract}
The purpose of this research was to determine the effect of gender, religiosity, and Love of Money on tax evasion ethics. The population of this research is individual taxpayers in Daerah Istimewa Yogyakarta. The sampling technique in the research used purposive sampling, with criteria (1) individual taxpayers in Gunungkidul regency, and (2) individual taxpayers who have taxpayer-identification numbers (NPWP). The sample in this research is an individual taxpayer in Gunungkidul regency who has an NPWP. The research data collection was carried out by distributing questionnaires directly to respondents who met the criteria. Data analysis techniques in the research used multiple linear regression analysis with SPSS tools. This research obtained 80 respondents who were dominated by male respondents (41 respondents), while 39 respondents were female. This research found that the ethics of tax evasion influenced by gender and Love of Money. Meanwhile, religiosity does not affect the ethics of tax evasion.
\end{abstract}

.Keywords: Ethics of Tax Evasion; Gender; Religiosity; Love of Money

\section{PENDAHULUAN}

Sumber penerimaan Negara Indonesia sampai saat ini masih mengandalkan sektor pajak. Hal ini terlihat dari komposisi penerimaan negara Indonesia yang didominasi dari sektor pajak. Namun, belum semua wajib pajak membayarkan pajaknya. Hal ini terbukti dari data realisasi penerimaan pajak selama 11 tahun terakhir yang belum pernah mencapai target yang telah ditentukan. Data persentase realisasi pajak tahun 2009-2019 disajikan pada tabel 1 .

Tabel 1. Realisasi Penerimaan Pajak Tahun 2009-2019 (Target dan Realisasi disajikan dalam Triliunan)

\begin{tabular}{|c|c|c|c|}
\hline Tahun & Target & Realisasi & Persentase \\
\hline 2009 & 577 & 545 & $94,5 \%$ \\
\hline 2010 & 662 & 628 & $94,9 \%$ \\
\hline
\end{tabular}

* Corresponding author's e-mail: amir.hidayatulloh@act.uad.ac.id

http://openjournal.unpam.ac.id/index.php/JIA 
Jurnal Ilmiah Akuntansi Universitas Pamulang - Vol. 9, No. 1, Januari 2021 - Nurachmi \& Hidayatulloh

\begin{tabular}{lrrr}
\hline 2011 & 764 & 743 & $97,3 \%$ \\
2012 & 885 & 836 & $94,5 \%$ \\
2013 & 995 & 921 & $92,6 \%$ \\
2014 & 1.072 & 985 & $91,9 \%$ \\
2015 & 1.294 & 1.055 & $81,5 \%$ \\
2016 & 1.539 & 1.283 & $83,4 \%$ \\
2017 & 1.283 & 1.147 & $89,4 \%$ \\
2018 & 1.424 & $1.315,9$ & $92,0 \%$ \\
2019 & $1.577,6$ & $1.332,1$ & $84,4 \%$ \\
\hline
\end{tabular}

Sumber: (Julita, 2020)

Tabel 1 menunjukan bahwa realisasi penerimaan pajak pada tahun 20092019 belum pernah mencapai target yang telah ditetapkan. Hal ini ditunjukan dengan persentase penerimaan pajak yang berkisar 80-95 persen. Data ini mengindikasi bahwa beberapa wajib pajak masih enggan untuk membayarkan pajaknya.

Pada tahun 2018, realisasi rasio kepatuhan SPT orang pribadi sebesar 63,9 persen. Angka ini menunjukan peningkatkan dibandingkan tahun 2017. Realisasi rasio kepatuhan SPT orang pribadi pada tahun 2017 adalah 58,9 $\%$ (Putera, 2018). Pada level Indonesia, realisasi rasio kepatuhan SPT orang pribadi meningkat, namun realisasi rasio kepatuhan SPT orang pribadi di Kabupaten Gunungkidul masih tergolong rendah (Pangaribowo, 2018), bahkan KPP Wonosari merupakan KPP yang memiliki penerimaan pajak paling rendah di Daerah Istimewa Yogyakarta. Persentasi penerimaan pajak di KPP Bantul $(89,72 \%)$, KPP Sleman $(86,73 \%)$, KPP Kota Yogyakarta $(84,76 \%)$, KPP Wates $(83,40 \%)$, sedangkan KPP Wonosari (76,20 \%) (Aditya, 2018).

Sejak perubahan ketentuan peraturan perundang-undangan perpajakan pada tahun 1983, Indonesia telah melakukan penggantian sistem pemungutan pajak yang semula official assessment system menjadi self assessment system. Self assessment system merupakan sistem yang memberikan kepercayaan kepada wajib pajak untuk menghitung, membayar dan melaporkan sendiri besarnya jumlah pajak yang terutang. Sehingga, adanya kepercayaan yang diberikan kepada wajib pajak akan menciptakan peluang besar bagi wajib pajak untuk melakukan penggelapan pajak.

Menurut Sandmo (2005); Sofha \& Utomo (2018), penggelapan pajak dinilai sebagai hal yang memiliki makna negatif dan tergolong tindakan kriminal karena dilakukan atas dasar menyalahi aturan undang-undang dan merugikan negara. Penggelapan pajak tergolong dalam rerangka hukum. Hal ini karena penggelapan pajak mengindikasikan adanya tindakan eksploitasi dalam hukum untuk mengurangi kewajiban pajak.

Menurut McGee \& Noronha (2007); Basri (2015) menyatakan bahwa alasan yang sering digunakan untuk membenarkan penggelapan pajak atas dasar moral adalah ketidakmampuan untuk membayar, korupsi pemerintah, tarif pajak yang tinggi atau tidak mendapatkan banyak imbalan atas

* Corresponding author's e-mail: amir.hidayatulloh@act.uad.ac.id http://openjournal.unpam.ac.id/index.php/JIA 
Jurnal Ilmiah Akuntansi Universitas Pamulang - Vol. 9, No. 1, Januari 2021 - Nurachmi \& Hidayatulloh

pembayaran pajak yang telah dilakukan. Lebih lanjut, McGee \& Noronha (2007); Sofha \& Utomo (2018), ada tiga pandangan terhadap persepsi penggelapan pajak. Pandangan pertama yaitu penggelapan pajak dikatakan tidak etis karena terkait dengan kewajiban seseorang atau manusia kepada Tuhan, masyarakat, dan negara. Pandangan kedua yaitu penggelapan pajak etis berkaitan dengan anggapan bahwa pemerintah sepatutnya tidak menerima uang dari pembayaran pajak. Pandangan ketiga yaitu penggelapan pajak memiliki kemungkinan etis karena adanya kebenaran, situasi dan kondisi.

Persepsi Etika Penggelapan Pajak, menurut Sofha \& Utomo (2018) salah satunya dipengaruhi oleh gender. Setiap gender akan menghubungkan pengalaman atau perilakunya di masa lalu dengan pola pikir yang dimiliki sehingga menimbulkan sikap yang berbeda pada setiap individu. Lebih lanjut, Tang, Kim, \& Tangs (2000); Dharma, Agusti, \& Kurnia (2016) menyatakan bahwa dalam kasus penggelapan pajak, laki-laki lebih banyak ditemui berperilaku menyimpang, melanggar aturan serta tata cara perpajakan. Menurut McGee \& Noronha (2007); Sofha \& Utomo (2018), seorang perempuan berani menunjukan sikap yang etis dengan melawan penggelapan pajak dibandingkan laki-laki. Hasil yang berbeda diungkapkan Basri (2015) yang menyatakan bahwa Etika Penggelapan Pajak tidak dipengaruhi oleh gender.

Faktor lain yang memengaruhi Etika Penggelapan Pajak adalah Religiusitas. Hal ini seperti yang diungkapkan oleh Sofha \& Utomo (2018) yang menyatakan bahwa Religiusitas berpengaruh terhadap Etika Penggelapan Pajak. Begitu pula dengan penelitian Hidayatulloh \& Syamsu (2020) yang menemukan hasil bahwa Religiusitas baik Religiusitas intrinsik dan Religiusitas ekstrinsik berpengaruh pada niat untuk menggelapkan pajak. Oleh karena itu, individu yang memiliki keyakinan agama yang kuat mampu mencegah perbuatan yang buruk dengan menimbulkan rasa bersalah pada dirinya sendiri, termasuk perilaku untuk menggelapkan atau menghindari pajak. Akan tetapi, hasil penelitian terdahulu juga ada yang menemukan bahwa Religiusitas tidak berpengaruh terhadap perilaku, baik persepsi etis mahasiswa, Etika Penggelapan Pajak, kepatuhan pajak, seperti Basri (2015); Hidayatulloh (2016); Hidayatulloh \& Sartini (2019); Palupi \& Hidayatulloh (2019); Abdurahman \& Hidayatulloh (2020).

Menurut Rosianti \& Mangoting (2014); Nauvalia, Hermawan, \& Sulistyani (2018), Abdurahman \& Hidayatulloh (2020), faktor lain yang memengaruhi Etika Penggelapan Pajak adalah Love of Money. Individu yang memiliki kecintaan uang tinggi, maka individu tersebut akan berupaya melakukan berbagai cara untuk memenuhi kebutuhan hidupnya, termasuk melakukan perilaku melanggar etika (Farhan, Helmy, \& Afriyenti, 2019). Namun, Hidayatulloh \& Sartini (2019) menyatakan bahwa Love of Money tidak berpengaruh terhadap perilaku etis.

Hasil penelitian terdahulu yang memperoleh hasil masih kontradiktif mengenai pengaruh gender, Religiusitas, dan Love of Money terhadap Etika 
Jurnal Ilmiah Akuntansi Universitas Pamulang - Vol. 9, No. 1, Januari 2021 - Nurachmi \& Hidayatulloh

Penggelapan Pajak. Oleh karena itu, peneliti ini mencoba menguji kembali pada wajib pajak di Kabupaten Gunungkidul.

\section{LANDASAN TEORI}

\section{Etika Penggelapan Pajak}

Menurut Keraf (1998), etika adalah filsafat moral atau ilmu yang membahas dan mengkaji nilai serta norma. Etika dapat didefinisikan sebagai refleksi kritis dan rasional mengenai nilai dan norma yang terkait dengan bagaimana manusia harus hidup sebagai manusia dan mengenai masalah-masalah kehidupan manusia dengan mendasarkan diri pada nilai dan norma-norma yang umum diterima. Penggelapan pajak adalah usaha yang dilakukan oleh wajib pajak untuk meringankan beban atau utang pajak dengan cara melanggar undang-undang. Penggelapan pajak dilakukan dengan melanggar undang-undang, maka penggelapan pajak tentunya dilakukan dengan cara tidak illegal (Mardiasmo, 2016).

\section{Gender}

Menurut Salsabila \& Prayudiawan (2011), gender adalah suatu konsep analisis yang digunakan untuk mengidentifikasi perbedaan laki-laki dan peremuan. Lebih lanjut, Basri (2015) menyatakan bahwa laki-laki memiliki kecenderungan persepsi etis yang rendah dibandingkan dengan perempuan. Hal ini disebabkan karena kebanyakan laki-laki berani mengambil risiko dan melakukan cara untuk mencapai keinginannya. Dua pendekatan yang biasanya digunakan untuk memberikan pendapat mengenai pengaruh gender terhadap perilaku etis atau persepsi individu terhadap perilaku tidak etis yaitu pendekatan struktural dan pendekatan sosialisasi. Pendekatan struktural yaitu perbedaan laki-laki dan perempuan yang disebabkan oleh sosialisasi awal terhadap pekerjaan serta kebutuhan-kebutuhan lainnya. Sedangkan, sosialisasi awal dipengaruhi oleh reward yang diberikan kepada individu dalam suatu profesi tertentu.

\section{Religiusitas}

Menurut Grasmick, Kinsey, \& Cochran (1991); Pemayun \& Budiasih (2018) menyatakan bahwa religisuitas dapat dikategorikan menjadi lima dimensi yaitu ideologis, ritualistik, pengalaman religiuitas, intelektual, dan konsekuensial. Dimensi ideologis berarti individu mengikuti aturan tertentu. Dimensi ritualistik yaitu bagaimana seseorang atau individu dalam prakteknnya mengikuti bermacam ajaran ilmu agama. Dimensi ketiga adalah pengalaman Religiusitas. Dimensi intelektual menekankan pada pengetahuan dalam bidang agama. Sedangkan, dimensi konsekuensial adalah dimensi yang dipergunakan untuk mendeteksi efek kepatuhan individu pada keempat dimensi sebelumnya.

\section{Love of Money}

Love of Money adalah perilaku individu pada uang, keinginan, dan aspirasi individu pada yang. Love of Money juga dapat diartikan sebagai tingkat kecintaan individu pada uang serta bagaimana individu tersebut menganggap uang itu sangat

* Corresponding author's e-mail: amir.hidayatulloh@act.uad.ac.id

http://openjournal.unpam.ac.id/index.php/JIA 
Jurnal Ilmiah Akuntansi Universitas Pamulang - Vol. 9, No. 1, Januari 2021 - Nurachmi \& Hidayatulloh

penting bagi kehidupannya. Love of Money terkait dengan sifat tamak dan rakus (Farhan et al., 2019). Menurut Tang \& Chiu (2003); Sofha \& Utomo (2018) menyatakan bahwa Love of Money merupakan hal yang sangat konseptual dan empiris serta perlu memperhatikan lebih lanjut karena dapat membantu, memprediksi, dan mengendalikan tindakan jahat atau tidak etis individu.

\section{Pengembangan Hipotesis}

Dari uraian latar belakang dan kajian teori, maka rerangka penelitian ini adalah sebagai berikut:

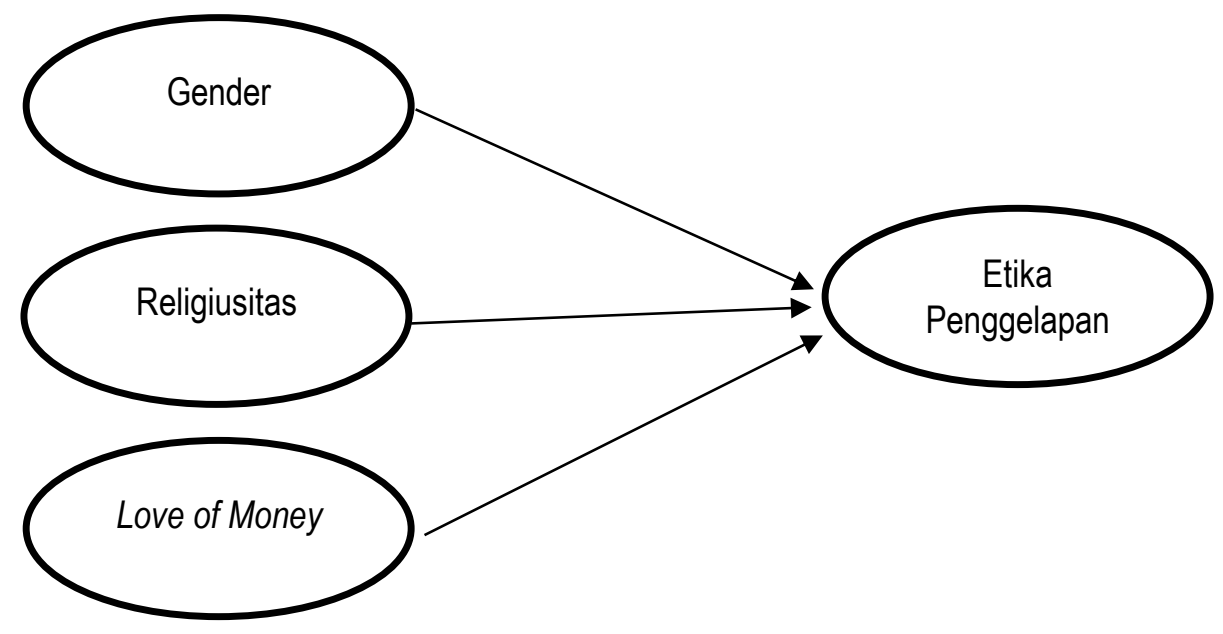

Gambar 1. Rerangka Penelitian

\section{Pengaruh Gender terhadap Etika Penggelapan Pajak}

Kepribadian buruk yang dimiliki oleh individu mendorong dirinya untuk berperilaku menyimpang, melanggar aturan serta tata cara dalam perpajakan. setiap gender akan menghubungkan pengalaman maupun perilakunya dimasa lalu dengan pola pikir yang dimiliki sehingga menimbulkan sikap yang berbeda pada masingmasing individu. Menurut Tang et al. (2000); Dharma et al (2016) menyatakan bahwa kasus Etika Penggelapan Pajak lebih banyak dilakukan oleh laki-laki dibandingkan perempuan. Pernyataan ini diperkuat oleh McGee \& Noronha (2007); Sofha \& Utomo (2018) yang menyatakan bahwa seorang perempuan berani menunjukan sikap yang etis dengan melawan penggelapan pajak dibandingkan dengan laki-laki. Oleh karena itu, hipotesis pertama (H1) penelitian ini adalah sebagai berikut:

H1: Gender berpengaruh terhadap Etika Penggelapan Pajak

\section{Pengaruh Religiusitas terhadap Etika Penggelapan Pajak}

Religiusitas dapat dilihat dari seberapa dalam pengetahuan, keyakinan, pelaksanaan ibadah dan kaidah-kaidah agama yang dilakukan oleh individu. Individu yang memiliki tingkat keyakinan agama yang kuat dapat mencegah perilaku yang buruk dengan menimbulkan rasa bersalah kepada dirinya sendiri termasuk dalam penghindaran pajak (Grasmick et al., 1991). Hal ini didukung oleh hasil penelitian Sofha \& Utomo (2018); Hidayatulloh \& Syamsu (2020), yang 
Jurnal Ilmiah Akuntansi Universitas Pamulang - Vol. 9, No. 1, Januari 2021 - Nurachmi \& Hidayatulloh

menyatakan bahwa Religiusitas berpengaruh terhadap Etika Penggelapan Pajak maupun niat untuk melakukan penggelapan pajak. Oleh karena itu, hipotesis kedua penelitian ini adalah sebagai berikut:

H2: Religiuistas berpengaruh terhadap Etika Penggelapan Pajak

\section{Pengaruh Love of Money terhadap Etika Penggelapan Pajak}

Menurut Farhan et al (2019), Love of Money adalah perilaku individu pada uang, keinginan, dan asipirasi individu pada uang. Love of Money juga dapat diartikan sebagai tingkat kecintaan individu pada uang dan bagaimana individu menganggap uang itu sangat penting bagi kehidupannya. Lebih lanjut, Farhan et al (2019) menyatakan bahwa apabila individu memiliki kecintaan akan uang yang tinggi, maka individu tersebut akan melakukan berbagai usaha untuk memenuhi kebutuhannya, termasuk dengan cara yang tidak etis. Semakin tinggi perilaku Love of Money yang dimiliki individu, maka semakin rendah etika yang dimiliki. Oleh karena itu, individu yang memiliki perilaku Love of Money memiliki kecenderungan untuk melakukan perbuatan tidak etis termasuk penggelapan pajak. Pernyataan ini didukung oleh hasil penelitian sebelumnya Nauvalia et al (2018); Abdurahman \& Hidayatulloh (2020) yang menyatakan bahwa Love of Money berpengaruh terhadap Etika Penggelapan Pajak maupun persepsi etis. Oleh karena itu, hipotesis ketiga penelitian ini adalah sebagai berikut:

H3: Love of Money berpengaruh terhadap Etika Penggelapan Pajak

\section{METODE PENELITIAN}

Populasi dalam penelitian ini adalah wajib pajak orang pribadi di Daerah Istimewa Yogyakarta. Teknik pengambilan sampel dalam penelitian ini menggunakan purposive sampling, dengan kriteria (1) wajib pajak orang pribadi di Kabupaten Gunungkidul, dan (2) wajib pajak orang pribadi yang memiliki Nomor Pokok Wajib Pajak (NPWP). Sampel dalam penelitian ini adalah wajib pajak orang pribadi di Kabupaten Gunungkidul yang memiliki NPWP. Pengumpulan data dalam penelitian dilakukan dengan menyebarkan kuesioner secara langsung kepada responden yang memenuhi kriteria. Variabel dalam penelitian terdiri dari variabel independen (gender, Religiusitas, dan Love of Money) serta variabel dependen (Etika Penggelapan Pajak). Definisi dan pengukuran masing-masing variabel disajikan pada tabel 2. Teknik analisis data penelitian ini menggunakan analisis regresi berganda dengan bantuan alat SPSS.

Tabel 2. Definisi dan Pengukuran Variabel

\begin{tabular}{|l|l|l|l|l|}
\hline Variabel & Definisi & Referensi & Pengukuran & Referensi \\
\hline $\begin{array}{l}\text { Etika } \\
\begin{array}{l}\text { Penggelapan } \\
\text { Pajak }\end{array}\end{array}$ & $\begin{array}{l}\text { Etika adalah tata } \\
\text { cara hidup yang } \\
\text { baik, aturan } \\
\text { hidup yang baik, } \\
\text { dan segala }\end{array}$ & (Keraf, 1998); & $\begin{array}{l}\text { Tiga belas item } \\
\text { pernyataan } \\
\text { dengan } \\
\text { menggunakan } \\
\text { skala likert lima }\end{array}$ & (Sofha \& \\
Utomo, 2018) \\
\end{tabular}

* Corresponding author's e-mail: amir.hidayatulloh@act.uad.ac.id http://openjournal.unpam.ac.id/index.php/JIA 
Jurnal Ilmiah Akuntansi Universitas Pamulang - Vol. 9, No. 1, Januari 2021 - Nurachmi \& Hidayatulloh

\begin{tabular}{|c|c|c|c|c|}
\hline & $\begin{array}{l}\text { kebiasaan yang } \\
\text { dianut serta } \\
\text { diwariskan dari } \\
\text { generasi yang } \\
\text { satu ke generasi } \\
\text { yang lain. } \\
\text { Sedangkan, } \\
\text { penggelapan } \\
\text { pajak adalah } \\
\text { suatu usaha yang } \\
\text { dilakukan oleh } \\
\text { wajib pajak } \\
\text { untuk } \\
\text { meringankan } \\
\text { utang pajak } \\
\text { dengan cara } \\
\text { melanggar } \\
\text { undang-undang. }\end{array}$ & & $\begin{array}{l}\text { poin, yaitu } \\
\text { Sangat Tidak } \\
\text { Setuju (1), Tidak } \\
\text { Setuju (2), Netral } \\
\text { (3), Setuju (4), } \\
\text { dan Sangat } \\
\text { Setuju (5) }\end{array}$ & \\
\hline Gender & $\begin{array}{l}\text { Berhubungan } \\
\text { dengan } \\
\text { keberadaan dua } \\
\text { jenis kelamin } \\
\text { yaitu laki-laki } \\
\text { dan perempuan }\end{array}$ & $\begin{array}{l}\text { (Salsabila \& } \\
\text { Prayudiawan, } \\
\text { 2011) }\end{array}$ & $\begin{array}{l}\text { Variabel dummy, } \\
\text { laki-laki (1) dan } \\
\text { perempuan (0) }\end{array}$ & - \\
\hline Religiuisitas & $\begin{array}{l}\text { Tingkat iman } \\
\text { atau nilai agama } \\
\text { yang diyakini } \\
\text { oleh individu }\end{array}$ & $\begin{array}{l}\text { (Pemayun \& } \\
\text { Budiasih, 2018) }\end{array}$ & $\begin{array}{l}\text { Tiga belas item } \\
\text { pernyataan } \\
\text { dengan } \\
\text { menggunakan } \\
\text { skala likert lima } \\
\text { poin, yaitu } \\
\text { Sangat Tidak } \\
\text { Setuju (1), Tidak } \\
\text { Setuju (2), Netral } \\
\text { (3), Setuju (4), } \\
\text { dan Sangat } \\
\text { Setuju (5) }\end{array}$ & $\begin{array}{l}\text { (Pemayun \& } \\
\text { Budiasih, 2018) }\end{array}$ \\
\hline Love of Money & $\begin{array}{l}\text { Tingkat } \\
\text { kecintaan } \\
\text { individu pada } \\
\text { uang dan } \\
\text { bagaimana } \\
\text { individu tersebut } \\
\text { menganggap } \\
\text { bahwa uang } \\
\text { sangat penting } \\
\text { bagi } \\
\text { kehidupannya }\end{array}$ & $\begin{array}{l}\text { (Farhan et al., } \\
\text { 2019) }\end{array}$ & $\begin{array}{l}\text { Dua belas item } \\
\text { pernyataan } \\
\text { dengan } \\
\text { menggunakan } \\
\text { skala likert lima } \\
\text { poin, yaitu } \\
\text { Sangat Tidak } \\
\text { Setuju (1), Tidak } \\
\text { Setuju (2), Netral } \\
\text { (3), Setuju (4), } \\
\text { dan Sangat } \\
\text { Setuju (5) }\end{array}$ & $\begin{array}{l}\text { (Sofha \& } \\
\text { Utomo, 2018) }\end{array}$ \\
\hline
\end{tabular}

* Corresponding author's e-mail: amir.hidayatulloh@act.uad.ac.id http://openjournal.unpam.ac.id/index.php/JIA 
Jurnal Ilmiah Akuntansi Universitas Pamulang - Vol. 9, No. 1, Januari 2021 - Nurachmi \& Hidayatulloh

\section{ANALISIS DATA DAN PEMBAHASAN}

Pengumpulan data dalam penelitian dilakukan dengan menyebarkan kuesioner secara langsung kepada responden yang memenuhi kriteria. Kuesioner yang memenuhi kriteria berjumlah 80 kuesioner, dan 80 kuesioner dapat diolah lebih lanjut. Responden dalam penelitian didominasi oleh responden berjenis kelamin laki-laki (41 responden), sedangkan 39 responden berjenis kelamin perempuan. Teknik analisis data dalam penelitian ini menggunakan analisis regresi linear berganda dengan bantuan SPSS. Sebelum pengujian hipotesis dilakukan, penelitian ini melakukan uji kualitas data (uji validitas dan uji reliabilitas), serta uji asumsi klasik (uji normalitas, uji multikolinieritas, dan uji heterokedastisitas). Penelitian ini memenuhi uji kualitas data dan uji asumsi klasik, dan tahap selanjutnya adalah pengujian hipotesis. Hasil pengujian hipotesis disajikan pada tabel 3 .

Tabel 3. Hasil Pengujian Hipotesis

\begin{tabular}{|c|c|c|c|}
\hline Variabel & Koefisien & Sig & Keterangan \\
\hline Gender & 5,805 & 0,003 & H1 terdukung \\
\hline Religiusitas & $-0,280$ & 0,131 & H2 tidak terdukung \\
\hline Love of Money & 0,561 & 0,000 & $\mathrm{H} 3$ terdukung \\
\hline Konstanta & $=25,404$ & & \\
\hline Variabel Dependen & $=$ Etika Penggelapan Pajak & & \\
\hline Adjusted $R$ Square & $=0,400$ & & \\
\hline F Statistik & $=18,520$ & & \\
\hline Signifikansi & $=0,000$ & & \\
\hline
\end{tabular}

Sumber: data primer, diolah dengan SPSS (2020)

Tabel 3 menunjukan bahwa penelitian ini memiliki nilai adjusted $R$-Square sebesar 0,400. Hal ini berarti variabel Etika Penggelapan Pajak dapat dijelaskan oleh variabel gender, Religiusitas, dan Love of Money sebesar $40 \%$, sedangkan 60 $\%$ dijelaskan oleh variabel lain di luar model.

Tabel 3 juga menunjukan bahwa Etika Penggelapan Pajak dipengaruhi oleh gender. Hal ini ditunjukan dengan nilai signifikasi $(0,003)$ yang lebih kecil dibandingkan dengan 0,05 . Atau dengan kata lain, hipotesis pertama $(\mathrm{H} 1)$ penelitian ini terdukung. Hal ini berarti bahwa kasus Etika Penggelapan Pajak lebih banyak dilakukan oleh laki-laki dibandingkan perempuan. Perempuan lebih berani menunjukan sikap etis untuk melawan penggelapan pajak dibandingkan dengan laki-laki. Hasil penelitian ini mendukung hasil penelitian sebelumnya Tang et al (2000); McGee \& Noronha (2007); Dharma et al (2016); Sofha \& Utomo (2018) yang menyatakan bahwa gender memiliki pengaruh pada Etika Penggelapan Pajak.

Faktor lain yang memengaruhi Etika Penggelapan Pajak adalah Love of Money. Hal ini ditunjukan dengan nilai signifikasi $(0,000)$ yang lebih kecil dibandingkan 0,05. Atau dengan kata lain, hipotesis ketiga (H3) penelitian ini terdukung. Hal ini berarti kecintaan akan uang adalah hal yang sangat konseptual dan empiris serta perlu diperhatikan lebih lanjut karena dapat membantu, memprediksi dan mengendalikan tindakan jahat atau tidak etis individu. Hal ini

* Corresponding author's e-mail: amir.hidayatulloh@act.uad.ac.id

http://openjournal.unpam.ac.id/index.php/JIA 
Jurnal Ilmiah Akuntansi Universitas Pamulang - Vol. 9, No. 1, Januari 2021 - Nurachmi \& Hidayatulloh

disebabkan karena apabila individu memiliki kecintaan akan uang tinggi, maka individu tersebut akan berusaha untuk melakukan segala cara agar kebutuhannya terpenuhi walaupun dengan melanggar etika. Oleh karena itu, semakin tinggi perilaku Love of Money maka semakin rendah etika yang dimiliki. Sehingga individu yang memiliki sikap Love of Money cenderung untuk melakukan perbuatan tidak etis seperti penggelapan pajak. Hasil penelitian ini mendukung hasil penelitian sebelumnya Nauvalia et al (2018); Abdurahman \& Hidayatulloh (2020) yang menyatakan bahwa Love of Money berpengaruh terhadap Etika Penggelapan Pajak maupun persepsi etis.

Religiusitas yang dimiliki individu tidak terbukti memengaruhi Etika Penggelapan Pajak. Hal ini ditunjukan dengan nilai signifikasi $(0,131)$ yang lebih besar dibandingkan dengan 0,05. Atau dengan kata lain, hipotesis kedua (H2) penelitian ini tidak terdukung. Hal ini berarti bahwa tinggi rendahnya tingkat Religiusitas individu belum mampu memengaruhi individu tersebut untuk berperilaku sesuai dengan norma yang ada. Oleh karena itu, saat individu melakukan perilaku tidak etis, individu tersebut tidak mempertimbangkan nilainilai Religiusitasnya. Pernyataan ini didukung oleh hasil penelitian Basri (2015) yang menyatakan bahwa religisuitas tidak berpengaruh terhadap Etika Penggelapan Pajak. Beberapa hasil penelitian sebelumnya juga menyatakan bahwa Religiusitas tidak berpengaruh pada perilaku tidak etis, seperti hasil penelitian Hidayatulloh (2016); Hidayatulloh \& Sartini (2019); Palupi \& Hidayatulloh (2019); Abdurahman \& Hidayatulloh (2020). Selain itu, menurut Hidayatulloh (2016); (Noermansyah \& Aslamadin, 2019) semakin besar pengaruh orang lain dari lingkungan wajib pajak untuk berperilaku tidak patuh, maka semakin besar niat ketidakpatuhan wajib pajak untuk membayar pajak. Atau dengan kata lain, perilaku wajib pajak untuk tidak patuh dipengaruhi oleh norma subjektif, seperti orang lain, atasan, rekan kerja, keluarga, dan lain sebagainya.

\section{KESIMPULAN DAN SARAN}

Penelitian ini memperoleh hasil bahwa Etika Penggelapan Pajak dipengaruhi oleh gender dan Love of Money. Hal ini berarti bahwa wajib pajak laki-laki memiliki kecenderungan untuk melakukan penggelapan pajak. Hal ini karena wajib pajak perempuan dianggap lebih berani menunjukan sikap etis untuk melawan penggelapan pajak. Selain itu, Love of Money juga memengaruhi Etika Penggelapan Pajak. Oleh karena itu, wajib pajak yang memiliki kecintaan uang yang tinggi, wajib pajak tersebut akan berusaha untuk melakukan berbagai cara agar pajak yang dibayarkan lebih sedikit dibandingkan yang sebenarnya walaupun dengan cara melakukan penggelapan pajak. Penelitian ini juga memperoleh hasil bahwa Etika Penggelapan Pajak tidak dipengaruhi oleh Religiusitas. Hal ini mengindikasikan bahwa tinggi rendahnya tingkat Religiusitas wajib pajak belum mampu memengaruhi wajib pajak untuk berperilaku dengan norma yang ada. Ketidakdukungan Religiusitas pada Etika Penggelapan Pajak juga disebabkan karena pengaruh norma subjektif, seperti keluarga, rekan kerja, atasan dan lain

* Corresponding author's e-mail: amir.hidayatulloh@act.uad.ac.id

http://openjournal.unpam.ac.id/index.php/JIA 
Jurnal Ilmiah Akuntansi Universitas Pamulang - Vol. 9, No. 1, Januari 2021 - Nurachmi \& Hidayatulloh

sebagainya. Semakin besar pengaruh orang lain dari lingkungan wajib pajak untuk berperilaku tidak patuh, maka semakin besar niat wajib pajak untuk tidak membayarkan pajaknya.

Tidak ada penelitian yang sempurna. Penelitian ini memiliki keterbatasan yaitu penelitian ini tidak membedakan wajib pajak berdasarkan profesinya, seperti PNS, wirausaha dan lain sebagainya. Oleh karena itu, penelitian selanjutnya dapat membedakan wajib pajak berdasarkan profesinya, seperti wajib pajak yang menerapkan self assessment system (wirausaha).

\section{DAFTAR PUSTAKA}

Abdurahman, N. L., \& Hidayatulloh, A. (2020). Kecerdasan, Religiusitas, Kecintaan Terhadap uang dan Persepsi Etis Mahasiswa Akuntansi Universitas Ahmad Dahlan Yogyakarta. Jurnal Aplikasi Akuntansi, 4(2), 211-225.

Aditya, I. (2018). Kanwil Ditjen Pajak DIY Kejar Target. Https://Www.Krjogja.Com. Retrieved from https://www.krjogja.com/beritalokal/diy/yogyakarta/kanwil-ditjen-pajak-diy-kejar-target/

Basri, Y. M. (2015). Pengaruh gender, Religiusitas dan sikap Love of Money pada persepsi Etika Penggelapan Pajak mahasiswa akuntansi. Jurnal Ilmiah Akuntansi Dan Bisnis, 10(1), 45-54.

Dharma, L., Agusti, R., \& Kurnia, P. (2016). Pengaruh Gender, Pemahaman Perpajakan Dan Religiusitas Terhadap Persepsi Penggelapan Pajak. JOM Fekon, 3(1).

Farhan, M., Helmy, H., \& Afriyenti, M. (2019). Pengaruh Machiavellian Dan Love of Money Terhadap Persepsi Etika Penggelapan Pajak Dengan Religiusitas Sebagai Variabel Moderasi: (Studi Empiris Pada Wajib Pajak Di Kota Padang). Jurnal Eksplorasi Akuntansi, 1(1).

Grasmick, H. G., Kinsey, K., \& Cochran, J. K. (1991). Denomination, Religiosity and Compliance with the Law: A Study of Adults. Journal for the Scientific Study of Religion, 30(1), 99. https://doi.org/10.2307/1387152

Hidayatulloh, A. (2016). Faktor-faktor yang mendorong wajib pajak pribadi untuk menggelapkan pajak. Optimum: Jurnal Ekonomi Dan Pembangunan, 6(2), 189-200.

Hidayatulloh, A., \& Sartini. (2019). Pengaruh Religiusitas dan Love of Money Terhadap Persepsi Etis Mahasiswa Akuntansi. Jurnal Akuntansi Universitas Jember, 17(1), 28-36.

Hidayatulloh, A., \& Syamsu, M. N. (2020). Religiusitas Intrinsik, Religiusitas Ekstrinsik, dan Niat Untuk Menghindari Pajak. JAK (Jurnal Akuntansi): Kajian Ilmiah Akuntansi, 7(1), 44-51. https://doi.org/10.1017/CBO9781107415324.004 
Jurnal Ilmiah Akuntansi Universitas Pamulang - Vol. 9, No. 1, Januari 2021 - Nurachmi \& Hidayatulloh

Julita, L. (2020). Hmm.. Sudah 11 Tahun, RI Tak Mampu Capai Target Pajak. CNBC Indonesia. from https://www.cnbcindonesia.com/news/20200108133413-4-128546/hmmsudah-11-tahun-ri-tak-mampu-capai-target-pajak

Keraf, S. (1998). Etika Bisnis Tuntutan Dan Relevansinya. Yogyakarta: Kanisius.

Mardiasmo. (2016). Perpajakan (2016th ed.). CV Andi.

McGee, R. W., \& Noronha, C. (2007). The Ethics of Tax Evasion: A Comparative Study of Guangzhou (Southern China) and Macau Opinion. Ssrn, 18(36), 133152. https://doi.org/10.2139/ssrn.1015882

Nauvalia, F. A., Hermawan, Y., \& Sulistyani, T. (2018). Pengaruh Religiusitas, Pemahaman Perpajakan, Status Sosial Ekonomi Dan Love of Money Terhadap Persepsi Penggelapan Pajak. Permana, 9(2).

Noermansyah, L. A., \& Aslamadin, I. (2019). Analisis Faktor-Faktor Yang Mempengaruhi Niat Ketidakpatuhan Wajib Pajak Daerah Di Kota Tegal. Jurnal Aset, 11(2), 329-339.

Palupi, A. L., \& Hidayatulloh, A. (2019). Studi Kepatuhan Wajib Pajak Orang Pribadi Wirausahawan di kabupaten Kulon Progo. Sistem Informasi, Keuangan, Auditing Dan Perpajakan, 4(1), 58-65.

Pangaribowo, W. S. (2018). Tingkat Kesadaran Masyarakat Gunungkidul Masih Rendah. Https://Jogja.Tribunnews.Com. Retrieved from https://jogja.tribunnews.com/2018/03/13/tingkat-kesadaran-masyarakatgunungkidul-masih-rendah

Pemayun, A. W., \& Budiasih, I. G. A. N. (2018). Pengaruh Religiusitas, Status Sosial Ekonomi dan Love of Money Pada Persepsi Etis Mahasiswa Akuntansi. E-Jurnal Akuntansi, 23(2), 1600-1628.

Putera, A. D. (2018, April 2). Rasio Kepatuhan Pelaporan SPT Wajib Pajak Orang Pribadi Meningkat. Https://Ekonomi.Kompas.Com.

Rosianti, C., \& Mangoting, Y. (2014). Pengaruh Money Ethics terhadap Tax Evasion dengan Intrinsic dan Extrinsic Religiosity sebagai Variabel Moderating. Tax \& Accounting Review, 4(1), 61. Retrieved from http://publication.petra.ac.id/index.php/akuntansi-pajak/article/view/3101

Salsabila, A., \& Prayudiawan, H. (2011). Pengaruh Akuntabilitas, Pengetahuan Audit Dan Gender Terhadap Kualitas Hasil Kerja Auditor Internal (Studi Empiris Pada Inspektorat Wilayah Provinsi DKI Jakarta). Telaah \& Riset Akuntansi, 4(1).

Sandmo. (2005). The Theory of Tax Evasion: A Retrospective View. National Tax Journal, 58(4), 643-663.

Sofha, D., \& Utomo, S. D. (2018). Keterkaitan Religiusitas, Gender, LOM Dan Persepsi Etika Penggelapan Pajak. Jurnal Ilmu Manajemen Dan Akuntansi Terapan (JIMAT, 9(2). 
Jurnal Ilmiah Akuntansi Universitas Pamulang - Vol. 9, No. 1, Januari 2021 - Nurachmi \& Hidayatulloh

Tang, T. L. ., \& Chiu, R. . (2003). Income, Money Ethics, Pay Satisfaction, Commitment, and Unethical Behavior: Is The Love Money the Root of Evil for Hongkong Employees?,. Journal of Business Ethics, 46, 13-30.

Tang, T. L. ., Kim, J. ., \& Tangs, D. S. . (2000). Does attitude towards money moderate the relationship between intrinsic job satisfaction and voluntary turnover? Human Relation, 53(2). 